\title{
Comparative Study About Youth Body Height by Age Group and BMI at Medical Faculty of UMM
}

\author{
Anung Putri Illahika ${ }^{1}$, Wiby Fahmi Wijaya ${ }^{2}$ \\ ${ }^{1}$ Department of Anatomy, Medical Faculty, University of Muhammadiyah Malang \\ J1. Bendungan Sutami No.188A Malang, \\ ${ }^{2}$ Student of Medical Faculty, University of Muhammadiyah Malang \\ Email : anungputri113@gmail.com
}

Receive : March 25th 2020 . Revised : May 15th 2020. Published: Jun 27th 2020

DOI: https://doi.org/10.22219/sm.Vol16.SMUMM1.12717

\begin{abstract}
Growth and development is a continuous process in the process of reaching adulthood, including the teenage stage. The problem that is often faced is physical change. Adolescent physical changes that appear are the increase in height and weight which affects the Body Mass Index (BMI). Height is one of the important things in adolescent growth and development. which is affected by genetic and environmental factors. The peak of growth in adolescents is different between boys and girls, so the pattern of height and BMI are also different. The purpose of this study was to determine differences in adolescent height based on age groups and BMI in Medical Faculty of UMM. This research is a comparative study by taking a sample of 100 medical students of UMM who have an age range of 17-20 years. The data to be taken is height measured using a MIC scale health scale ratio ratio. The measurement results have a numerical scale with units of centimeters $(\mathrm{cm})$. Body mass index (BMI) is an index obtained from the division of body weight with height ${ }^{2}$. The measurement results are stated in $\mathrm{kg} / \mathrm{m} 2$. All data obtained will be analyzed using the ANOVA comparative test. ANOVA test results generated $\mathrm{p}$ value in the two groups of students> 0.05 which concluded that the mean height of the student body based on age and BMI was not significantly different (not significant) statistically for both men and women. The conclusion from this study there were no differences in adolescent height based on age groups and BMI among medical students of UMM.
\end{abstract}

Keywords : height, age, BMI.

Copyright $($ C) 2020, First Author et al This is an open access article under the CC-BY-SA license

\section{INTRODUCTION}

Adolescents, according to WHO, are individuals who are in the transition phase between childhood and adulthood. The age limit for teens according to WHO is 12 to 24 years. In 1974, WHO (World Health Organization) provided a more conceptual definition of adolescents. In the definition three criteria are stated, namely biological, psychological, and socioeconomic, so that the complete definition reads as follows. Teenagers are a period where: 1) The individual develops from the first time he shows his secondary sexual signs until he reaches sexual maturity. 2) Individuals experience psychological development and identification patterns from childhood to adulthood. 3) There is a transition from full socio-economic dependence to a relatively more independent state. In the stages of development adolescents occupy positions after childhood and before adulthood. 
The existence of major changes in the stages of adolescent development both physical changes including height and psychological changes (in women after experiencing menarche and in men after experiencing wet dreams) causes adolescence is relatively volatile compared to other developmental periods.

Physical development are changes in the body, brain, sensory capacity, and motor skills, it can be added that changes in the body are characterized by height and weight gain, bone and muscle growth, and maturity of the sexual organs and reproductive functions.

Height is one of the important things in adolescent growth and development. which is influenced by genetic and environmental factors (Wahyuni et al; 2011). Height is an anthropologically important examination to determine racial differences. Height estimation is also considered important in the medicolegal field, where height determination is the main step in the process of identifying subjects when only a part of the body is found..

Estimation of height based on long bones is one of the most widely used methods because it has good correlation and has been used in medicolegal cases (Sulijaya, 2013). There are several standard formulas that use long bone size in predicting height, such as the formula of Karl Pearson, Trotter and Gleser, Dupertuis and Hadden, as well as the Ragawi Anthropology formula. Studies to develop an equation for the measurement of adolescent height based on age groups and Body Mass Index (BMI) are still rare in Indonesia.

\section{METHODS}

This research was a comparative study by taking a sample of 100 FK UMM students whose age range of 17-20 years. The data to be taken was height measured using a MIC health scale ratio. The measurement results had a numerical scale with units of centimeters $(\mathrm{cm})$. Body mass index (BMI) was an index obtained from the division of body weight with height ${ }^{2}$. The measurement results were stated in $\mathrm{kg} / \mathrm{m}^{2}$.

All data obtained will be analyzed using the ANOVA comparative test..

\section{RESULTS}

In this study, the relationship between height based on age and BMI will be tested on male and female FK UMM students. The statistical method used is the one way ANOVA / Kruskal Wallis test because age is considered a group (only consisting of 17-19). From the results of the normality test produced that the data are normally distributed. ANOVA test results can be seen in the following table :

Table 1. Mean Height Measurement Results by Age

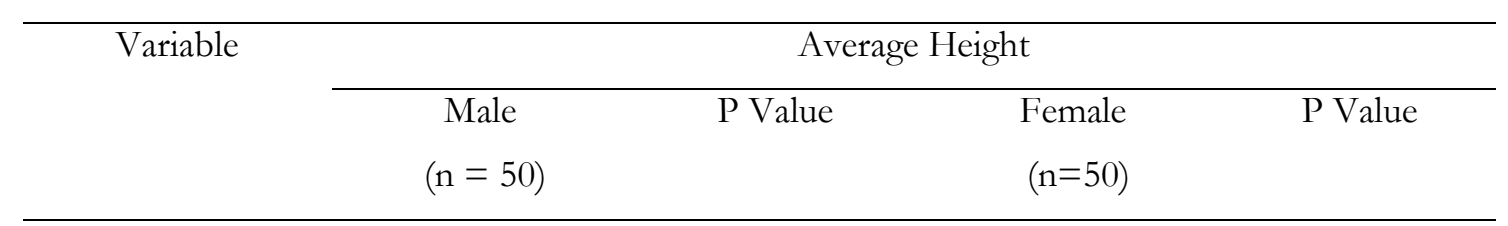




\begin{tabular}{llccc}
\hline Age & & & & \\
17 years old & 169.0000 & 0.511 & 161.0000 & 0.533 \\
18 years old & 172.3125 & & 158.0000 & \\
19 years old & 170.9000 & & 157.3182 & \\
\hline BMI & & & - & 0.743 \\
Underweight & 171.7500 & 0.399 & 158.0789 & \\
Normal & 171.0000 & & 156.7778 & \\
Overweight & 176.3333 & & 159.6667 & \\
Obese & 170.3571 & & & \\
\hline
\end{tabular}

From the results of the tabulation above, it is known that the average height for male students between the ages of 17 and 19 is not too far away, as is the case for female students. Statistically the difference in height is not significant $(p>0.05)$.

Meanwhile, the average height based on BMI on male students is known that students who are overweight have the highest average height. Whereas female students tend to be almost the same. From the ANOVA test results $\mathrm{p}$ value in the two groups of students $>0.05$ which concluded that the mean height of the student body based on BMI was not significantly different (not significant) both in male and female.

\section{DISCUSSION}

Height is one of the most important anthropometric parameters. Growth of height follows a common type of growth pattern. The results of the study in a sample group of men and women aged 17-20 years found that male had a higher tendency for height compared to female.

This is consistent with the theory that an increase in height usually occurs one year after puberty, namely men at the age of 9 years old and women at the age of 8 years old then decreases slowly after the age of 21. The growth of male is longer than female (Bangun \& Batubara, 2012). Artaria's study (2012) states that at the age of 13-19 years, male have higher height than female. That is because at the age of 12 years male experience rapid height growth compared to female.

Body Mass Index (BMI) is a tool or a simple way to monitor the nutritional status of adults, especially those related to underweight and overweight. Underweight can increase the risk of infectious diseases, whereas more weight will increase the risk of degenerative diseases. Therefore, maintaining a normal body weight allows a person to reach a longer life expectancy (MOH, 2017). This study found that the average male BMI is greater than women. The results of this study are in accordance with the BMI threshold determined by referring to WHO provisions that distinguish threshold limits for male and female. It was stated that the normal threshold for male is: 20.1-25.0 
$\mathrm{kg} / \mathrm{m}^{2}$; and for female: $18.7-23.8 \mathrm{~kg} / \mathrm{m}^{2}$. From the WHO provisions it was found that the threshold threshold for male IMT is greater than for female.

The results of the description of height based on age show that the group of male gets older the more height they gain. But this did not occur in the group of female where the highest average height was obtained at 17 years compared to other age groups. These results can be due to the smallest number of sample groups of female aged 17 years compared to other age groups. In addition, the results of the study are in accordance with the results of research Muljati and colleagues (2016) that changes in height are not so real until middle age. For male aged 16-18 years, they had an average height of $163.2 \mathrm{~cm}$, and an increase in height at the age of 19-20 years with an average of $164.2 \mathrm{~cm}$. In female aged 16-18 years, they had an average height of $153.7 \mathrm{~cm}$, and a decrease in height at the age of 19-20 years $153.2 \mathrm{~cm}$ (Muljati,2016).

The results of research on body image based on BMI showed that groups of male and female with obese value on BMI had the lowest mean muscle mass. In the group of female, the lowest average height was obtained from overweight IMT, the highest average height was obtained from obese BMI. But this did not happen to the group of male where the lowest average height was found in obese BMI, the highest average height was found in overweight BMI. This can happen because the body composition of each individual is different. Individuals with overweight or obese do not necessarily have more muscle mass than individuals with normal or underweight categories (Sherwood, 2012).

The above results support the results of research conducted by Janssen (2014) in men having a ratio of trunk muscle mass reaching $20 \%$ more than appendicular, whereas in female the ratio is almost the same. This can occur because the muscle mass of the male trunk is bigger and more stable than that of female, which is characterized by a broader chest and back. The trunk plays an important role in maintaining a stable posture against gravity so that it can provide stability to the proximal parts of the extremities and head. The trunk also plays an important role in stabilizing the lower extremities and knee movements during various activities (Wowiling, 2016). In female\&\#39;s trunk there is a specific distribution of fat which is the opposite of muscle mass. Female have specific fats that begin to appear since puberty and are spread in the breast area, lower abdomen and around the genitals so that they are different from men, the distribution pattern of female has a characteristic at puberty (Sudibjo, 2012).

\section{REFERENCES}

Artaria M, 2012, Perbedaan antara Laki-laki dan Perempuan: Penelitian Antropometris pada Anak-

Anak Umur 6-19 tahun, Jurnal Masyarakat Kebudayaan dan Politik Tahun 22 (4): 343-349

Batubara RL, 2010, Adolescent Development (Perkembangan Remaja), Sari Pediatri, 12(1), pp.21-29

Depkes RI, 2017, Pedoman Praktis untuk Mempertahankan Berat Badan Normal Berdasarkan Indeks Massa Tubuh (IMT) Dengan Gizi Seimbang, Jakarta. 
Janssen I, 2014, Skeletal muscle mass and distribution in 468 men and women aged 18-88 yr. J Appl Physiol, (89), pp.81-88.

Muljati S, Triwinarto A, Utami N, Hermina, 2016, Gambaran Median Tinggi Badan dan Berat Badan Menurut Kelompok Umur Pada Penduduk Indonesia yang Sehat Berdasarkan Hasil Riskesdas 2013, Penelitian Gzi dan Makanan, Desember 2016 Vol.39 (2):137-144.

Sherwood, L, 2012, Human Physiology: From Cells To Systems, Sub bab:Energy Balance and Temperature Regulation,Ed 7, Brooks Cole, USA

Sudibjo P, 2012, Penilaian Presentase Lemak Badan pada Populasi Indonesia dengan Metode Anthropometris, Jurnal Staff UNY, hal.20-36

Wowiling P, 2016, Pengaruh Latihan Core-Strengthening Terhadap Stabilitas Trunkus Dan Keseimbangan Pasien Pasca Stroke. Jurnal Biomedik (JBM), 8(1), Pp.43-50. 